\title{
STRATEGI PENGEMBANGAN EKOWISATA BERBASIS EKONOMI KEARIFAN LOKAL: SEBUAH KASUS DI KAMPUNG TAJUR, PURWAKARTA
}

\author{
Indra Maulana ${ }^{1}$; Muchammad Chusnan Aprianto ${ }^{2}$ \\ ${ }^{1}$ Sekolah Tinggi Ilmu Ekonomi DR. KHEZ Muttaqien \\ ${ }^{2}$ Sekolah Tinggi Teknologi DR. KHEZ Muttaqien
}

\begin{abstract}
Abstrak
Kampung Tajur terletak di Desa Pasanggrahan, Kecamatan Bojong, Purwakarta. Kampung ini dicanangkan sebagai desa berbasis ekowisata pada tahun 2004. Kampung Tajur menawarkan wisata alam dan budaya yang menjadi daya tarik wisatawan baik nusantara maupun mancanegara. Ciri khas obyek wisata yang ditawarkan sejenis dengan obyek wisata alam lain, namun daya tarik wisatawan pada wisata Kampung Tajur masih rendah. Artikel ini menggambarkan strategi rencana pengembangan ekowisata untuk Kampung Tajur berbasis kearifan lokal. Quantitative strategic planning matrix (QSPM) dengan angka fuzzy digunakan untuk menentukan prioritas strategi pengembangan ekowisata. Community-based ecotourism (CBET) berbasis sustainable tourism indicator (STI) dimanfaatkan sebagai indikator untuk menentukan beberapa strategi pengembangan sesuai dengan kearifan lokal masyarakat. Hasil penelitian diharapkan mampu memberikan masukan bagi stakeholders untuk pengembangan wisata daerah.
\end{abstract}

Kata kunci : Ekowisata, logika fuzzy, pengembangan wilayah, kearifan lokal.

\section{Pendahuluan}

Pembangunan sektor pariwisata merupakan salah satu sektor unggulan (leading sector) dalam perekonomian Nasional yang senantiasa perlu dikembangkan dan ditingkatkan. Jika ditinjau dari aspek sosial ekonomi dapat meningkatkan pendapatan masyarakat, perluasan kesempatan kerja, meningkatkan pendapatan pemerintah, peningkatan penerimaan devisa meningkatkan kewirausahaan Nasional dan dapat turut mendorong pembangunan di daerah.

Sektor pariwisata mempunyai posisi yang spesial dalam memberikan manfaat bagi komunitas baik secara ekonomis maupun sosial. Pariwisata menghasilkan peluang yang besar untuk menyejaterakan masyarakat sekaligus menghadirkan ancaman dan tantangan pada komunitas lokal dan lingkungan (Büscher dan Davidov, 2016).

Perkembangan sektor pariwisata pada saat ini terutama pada sektor ekowisata yang berbasis pada sumber daya alam dan budaya semakin menarik minat wisatawan baik nusantara maupun mancanegara. Ekowisata bertanggung jawab pada peningkatan kesejahteraan masyarakat dengan mengutamakan pelestarian lingkungan daerah-daerah alami yang terdapat pada lokasi wisata (Candrea dan Anu, 2015). Menghindari eksploitasi yang berlebihan diperlukan peningkatan dan pengembangan konservasi aset ekologis melalui 
pembangunan ekowisata yang berkelanjutan (Paresashvili, 2014). Pada prinsip berkelanjutan ini, fokus utama nya ada pada pengalaman dan pembelajaran tentang alam yang dikelola secara etis, berorientasi pada kearifan lokal dan dapat memberikan kontribusi bagi pelestarian konservasi aset ekologis.

Potensi ekowisata dalam pelestarian keanekaragaman hayati dapat dijadikan arah sebagai penciptaan lapangan kerja dalam bentuk promosi budaya dan produk-produk yang dibuat oleh masyarakat lokal tanpa mengorbankan pelestarian alam serta ciri khas budaya setempat

Purwakarta memiliki warisan alam unik yang menawarkan kesempatan sangat baik bagi pengembangan daya tarik destinasi

\section{Metode Penelitian}

Penelitian ini dilakukan di Kampung Tajur, Desa Pasanggrahan, Kabupaten Purwakarta. Data potensi daerah dan potensi pengembangan ekowisata diperoleh dengan wawancara mendalam kepada tokoh masyarakat dan tokoh pemuda Kampung Tajur. Wawancara mendalam dilakukan kepada tiga tokoh masyarakat (TM A, TM $\mathrm{B}$, dan TM C) yang dianggap berpengaruh oleh masyarakat yaitu ketua dan sekretaris RT serta salah satu warga desa. Selain itu, dilakukan wawancara kepada perwakilan dua pemuda Kampung Tajur. Kriteria penilaian strategi pengembangan diperoleh dari seleksi indikator ekowisata (Sikkim dkk., 2017) dan community-based ecotourism dan pariwisata keberlanjutan (Bulatović dan Rajović, 2016). Kriteria ini menjadi dasar dalam penentuan indikator faktor internal dan eksternal. wisata yang berkaitan dengan alam. Kampong Tajur merupakan salah satu destinasi wisata yang berkenaan dengan wisata alam dengan focus pada wisata edukasi. Keterlibatan stakeholders dalam perencanaan dan pengelolaan ekowisata di Kampung Tajur masih sangat rendah.

Mengingat masalah diatas, makalah ini bertujuan untuk menguraikan peluang dan tantangan utama dalam pengembangan destinasi ekowisata di Kampung Tajur Kabupaten Purwakarta. Menggunakan pendekatan Quantitative strategic planning matrix (QSPM) dengan angka fuzzy, hal tersebut akan dicoba diarahkan untuk pengembangan dan pengelolaan destinasi ekowisata di Kampung Tajur Kabupaten Purwakarta.

Setelah itu, dilakukan penyebaran kuisioner ke 30 responden untuk menentukan nilai bobot kriteria dan nilai kriteria pada masing-masing indikator strategi. Nilai bobot ditentukan menggunakan skala pengukuran semantik diferensial 5 titik dengan nilai 0 sampai dengan 1 dan interval 0,2. Nilai kriteria untuk masing-masing strategi dihitung menggunakan skala Fuzzy dengan persamaan $\left(a_{1}+2 a_{2}+a_{3} / 2\right) \cdot a_{1}, a_{2}$, dan $a_{3}$ adalah nilai Fuzzy untuk setiap tingkatan kondisi. Skala Fuzzy menggunakan enam tingkatan kondisi yaitu sangat rendah, rendah, sedang, baik, sangat baik, baik sekali, sangat baik sekali. Prioritas potensi pengembangan ditentukan dengan Fuzzy Quantitative Strategic Planning Matrix (FQSPM). 


\section{Indikator Ekowisata Berkelanjutan}

Beberapa wilayah memanfaatkan pariwisata sebagai salah satu aspek penting bagi perekonomian masyarakat. Saat ini, pariwisata alam dan budaya merupakan obyek yang menjadi daya tarik bagi wisatawan. Daya tarik pariwisata perlu dijaga keberlanjutannya agar memperkuat perekonomian masyarakat di wilayah pariwisata. Pariwisata berkelanjutan mempunyai tiga ciri yaitu: 1) Memanfaatkan secara optimal sumber daya lingkungan yang merupakan elemen kunci dalam pengembangan pariwisata; 2) Memelihara ekologi flora dan fauna untuk melestarikan warisan alam dan plasma nutfah; 3) Menghormati nilai-nilai sosial-budaya asli masyarakat lokal; 4) Berkontribusi pada pemahaman dan toleransi antar budaya; 5) Memastikan operasi ekonomi jangka panjang yang layak; 6) Memberikan manfaat sosial ekonomi bagi semua Pemangku kepentingan yang terbagi secara merata termasuk lapangan kerja yang stabil dan peluang pendapatan dan layanan sosial untuk menampung masyarakat; dan 7) berkontribusi terhadap pengentasan kemiskinan (Bulatović dan Rajović, 2016)

Indikator pariwisata keberlanjutan dipandang sebagai elemen penting dalam menjaga pariwisata keberlanjutan. Penggunaan indikator memberikan cara yang obyektif untuk mengukur dan memantau keberlanjutan kegiatan pariwisata. Bulatović dan Rajović (2016) telah mengembangkan indikator pariwisata keberlanjutan berdasarkan community-based ecotourism yang terdiri berasal dari permasalahan sosial, ekonomi, dan lingkungan. Selain itu, Sikkim, dkk. (2017) mengembangkan penilaian indikator ekowisata yang dimanfaatkan untuk melihat efektifitas kegiatan pariwisata di lapangan.

Tabel 1. Kerangka Evaluasi Permasalahan dan Indikator.

\begin{tabular}{|c|c|c|}
\hline eberlan & Community-based & Kriteria Ekowis \\
\hline $\begin{array}{l}\text { Permasalahan Sosial } \\
\text { - Kepuasan lokal terhadap } \\
\text { wisatawan } \\
\text { - Komplain komunitas } \\
\text { lokal } \\
\text { - Pengaruh wisatawan } \\
\text { terhadap pengembangan } \\
\text { infrastruktur dan } \\
\text { pengaruh lain terhadap } \\
\text { komunitas } \\
\text { - Pendidikan wisatawan } \\
\text { - Pendidikan masyarakat } \\
\text { lokal } \\
\text { Pelatihan pengembangan } \\
\text { keahlian untuk } \\
\text { masyarakat dan staf } \\
\text { kepariwisataan } \\
\text { Struktur pengambilan } \\
\text { keputusan di masyarakat }\end{array}$ & $\begin{array}{l}\text { Permasalahan Sosial } \\
\text { - } \quad \text { Pendidikan wisatawan } \\
\text { - } \text { Pendidikan komunitas } \\
\text { - } \text { Pelatihan pengembangan } \\
\text { keahlian untuk } \\
\text { masyarakat dan staf } \\
\text { kepariwisataan } \\
\text { - Struktur pengambilan } \\
\text { keputusan di masyarakat } \\
\text { - Manfaat masyarakat dari } \\
\text { ekowisata } \\
\text { - Konservasi } \\
\text { penghargaan budaya } \\
\text { Permasalahan Lingkungan } \\
\text { - Keterlibatan masyarakat } \\
\text { dalam kegiatan } \\
\text { konservasi }\end{array}$ & 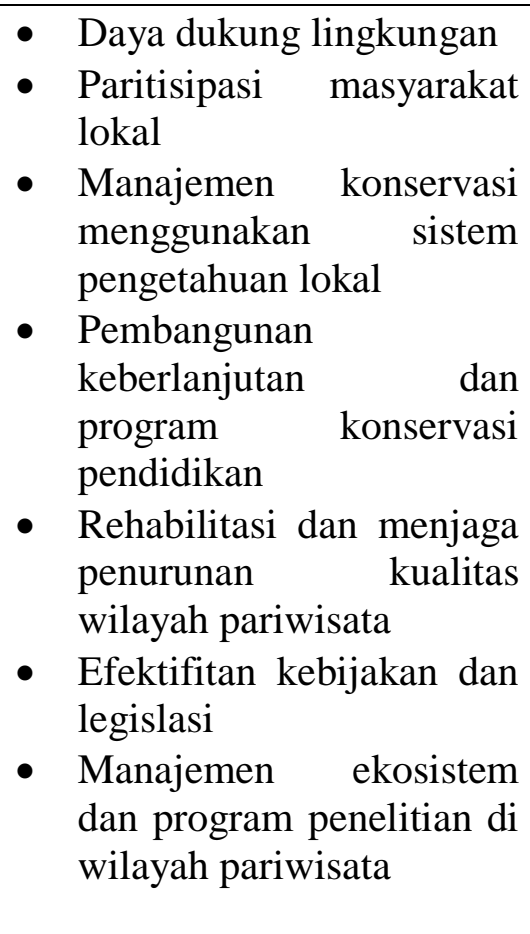 \\
\hline
\end{tabular}




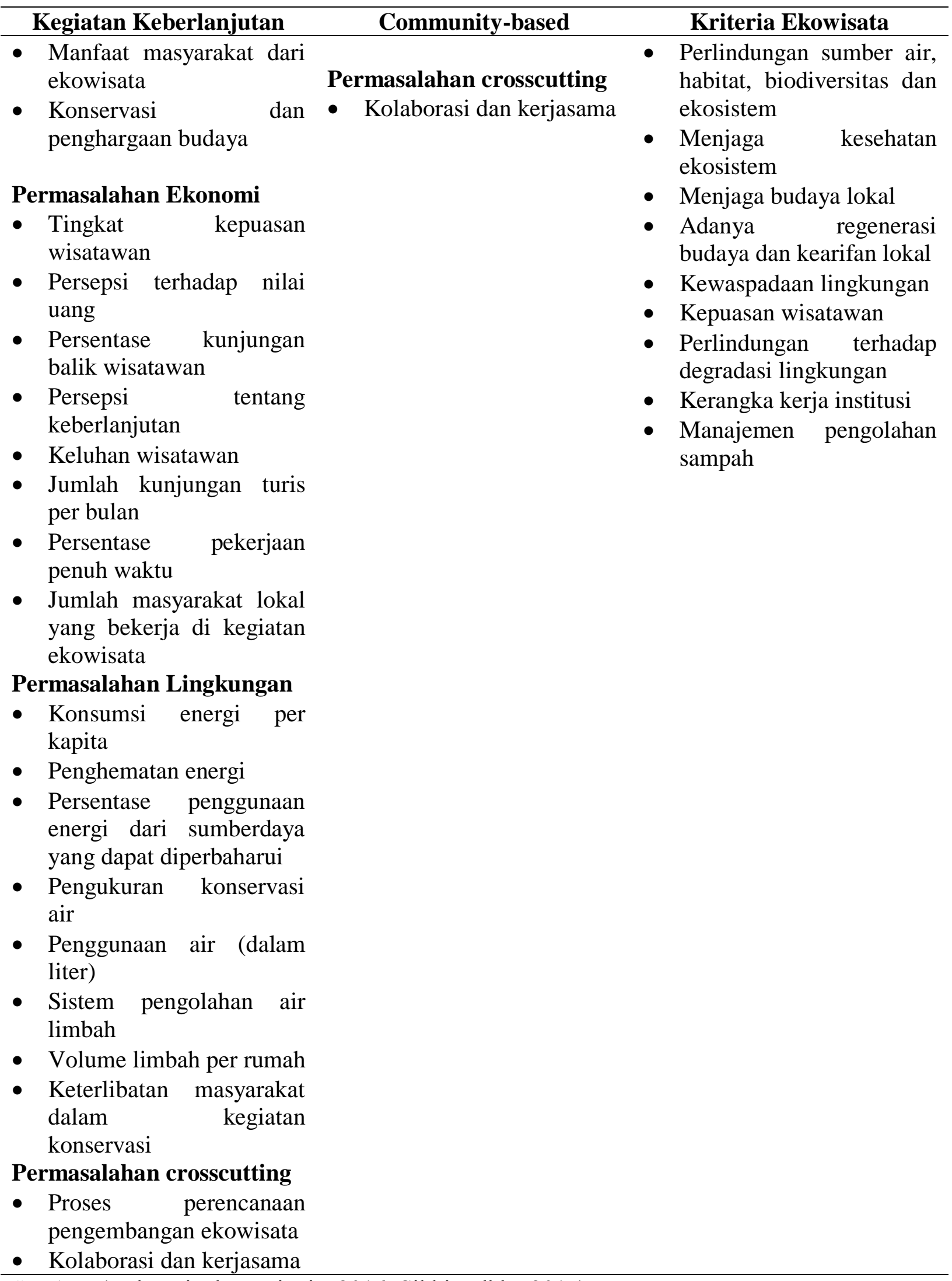

Sumber: (Bulatović dan Rajović, 2016; Sikkim dkk., 2017). 
Tabel 1 menunjukkan tiga indikator untuk pariwisata sebagai ukuran kondisi eksisting, ukuran risiko, sarana dan prasarana, dan potensi wilayah pariwisata. Indikator juga dapat dipakai sebagai ukuran perencanaan dan pelaksanaan program.

\section{Identifikasi Potensi Kampung Tajur}

Identifikasi potensi Kampung Tajur dilakukan melalui wawancara mendalam dengan tokoh masyarakat dan tokoh pemuda Kampung Tajur. Wawancara dengan salah satu tokoh masyarakat menggambarkan kondisi ekowisata Kampung Tajur sebagai berikut:

"Kalau untuk daerah wisata, kami mah hanya menawarkan

kesederhanaan hidup di desa, terus rumah hitam putih warna khas Purwakarta sesuai arahan bapak (bupati). Terus di sini mah rumah panggung $90 \%$, ya hanya $10 \%$ saja yang permanen" (TM A)

Berdasarkan hasil wawancara (TM A), saat ini obyek wisata yang ditawarkan adalah wisata sosial dan budaya. Wisata sosial yang ditawarkan adalah kehidupan masyarakat desa yang menjadi salah satu daya tarik wisatawan dari perkotaan yang tidak pernah merasakan kehidupan desa atau wisatawan yang rindu kehidupan di desa. Salah satu aspek budaya penting adalah masyarakat Kampung Tajur masih menjaga keberadaan rumah panggung sebagai rumah adat dan menjadi potensi sebagai warisan dan cagar budaya masyarakat lokal.

Saat ini, Kampung Tajur hanya menawarkan kesederhanaan hidup masyarakat desa tetapi Kampung Tajur memiliki beberapa potensi sebagai salah satu obyek ekowisata. Hasil wawancara menunjukkan bahwa ada potensi lain yang belum dikelola oleh masyarakat dan pemerintah daerah yaitu kegiatan adat dan
Indikator dapat mengukur: a) perubahan struktur kepariwisataan dan faktor internal, b) perubahan faktor eksternal yang mempengaruhi pariwisata dan c) dampak yang ditimbulkan oleh pariwisata.

budaya lokal yang saat ini telah ditinggalkan oleh masyakarat Tajur.

"Dulu waktu abdi (saya) kecil, pernah ada kegiatan adat sapartos (seperti) seni budaya hajat bumi dan tolak bala. Mung (namun), sekarang mah sudah tidak ada lagi, sudah ditinggalkan. Orang-orang tua juga sudah tidak tahu budaya ini apalagi yang mudanya. Padahal nya, saemut (ingat) saya mah tolak bala itu hanya berkumpul di tempat perempatan jalan terus baca tawasulan sareng (dan) doa-doa. Tapi nya mungkin ada perbedaan pendapat (pendapat agama) jadi sekarang banyak ditinggalkan, ditambah sesepuh juru kunci (tokoh masyarakat kunci) sudah meninggal.” (TM B)

Selain itu, Kampung Tajur memiliki potensi wilayah untuk dikembangkan sebagai wisata alam berupa air terjun, kolam mata air, dan bukit pandang untuk melihat pemandangan kota dan kegiatan perkemahan. Potensi ini muncul ketika dilakukan wawancara dengan pemuda desa (PM A).

"Upami cai (kalau air) penduduk
pakai air sumber (mata air) dari bukit,
terus dialirkan ke kampung pakai
selang. Di atas (bukit) juga ada air
terjun alam, tapi jaraknya dua jam.
Terus sekitar lima ratus meter ada
juga lapangan masih di wilayah Tajur
bisa dipakai untuk kemping
(perkemahan) dan melihat

"Upami cai (kalau air) penduduk pakai air sumber (mata air) dari bukit, terus dialirkan ke kampung pakai selang. Di atas (bukit) juga ada air terjun alam, tapi jaraknya dua jam. Terus sekitar lima ratus meter ada juga lapangan masih di wilayah Tajur (perkemahan) dan melihat 
pemandangan kota kalau malam hari.” (PM A)

Berdasarkan wawancara dengan tokoh masyarakat, dahulu Kampung Tajur memiliki kesenian tradisional angklung. Hasil wawancara ditunjukkan sebagai berikut:

"Dulu juga pernah ada kesenian angklung atau calung. Ya karena tidak ada yang melatih dan penerusnya jadi kesenian angklung tidak ada lagi." (TM A)

"Oh makanan ciri khas naon nya (apa ya), nya paling cuma makanan kampung saja kayak raginang, teh, opak, sampeu (singkong) ciri khas lain tidak ada." (TM C)
Hasil wawancara di atas menunjukkan bahwa kesenian daerah banyak ditinggalkan oleh masyarakat. Selain itu, masyarakat Tajur belum menggali potensi makanan dan minuman tradisional mengingat kondisi tanah Kampung Tajur yang subur.

Berdasarkan hasil wawancara mendalam, maka dapat dirumuskan sasaran potensi pengembangan ekowisata Kampung Tajur sebagai berikut:

1. Pengembangan kegiatan masyarakat adat (Strategi 1)

2. Pengembangan potensi wisata alam (Air terjun dan bukit pandang) (Strategi 2)

3. Pengembangan kesenian musik tradisional (Strategi 3)

4. Pengembangan makanan tradisional (Strategi 4).

\section{Analisis SWOT untuk Kriteria Ekowisata Berdasarkan Kearifan Lokal}

Prioritas strategi pengembangan ekowsiata dirumuskan menggunakan QSPM dengan modifikasi penilaian Angka Fuzzy. Analisis SWOT dipakai untuk menentukan kriteria berdasarkan indikator ekowisata, community-based, dan kegiatan keberlanjutan sesuai Tabel 1. Kriteria faktor yang berpengaruh dan sesuai dengan kondisi Kampung Tajur ditunjukkan pada Tabel 2 dengan menyertakan nilai pembobotan. Nilai bobot ini diperoleh dari penilaian hasil survey kepada tokoh masyarakat dan tokoh pemuda serta kesepakatan dengan tokoh masyarakat dan tokoh pemuda.

Tabel 2. Hasil Analisis SWOT dan Faktor yang Berpengaruh.

\begin{tabular}{|c|c|c|}
\hline SWOT & Faktor yang Berpengaruh & Bobot \\
\hline \multirow{3}{*}{ Strengths (kekuatan) } & Pendidikan masyarakat (k1) & 0,04 \\
\hline & Perlindungan terhadap degradasi lingkungan (k2) & 0,07 \\
\hline & Inovasi obyek wisata alam dan lokal (k3) & 0,12 \\
\hline \multirow{3}{*}{$\begin{array}{l}\text { Weakness } \\
\text { (kelemahan) }\end{array}$} & Rendahnya Partisipasi masyarakat lokal (k4) & 0,03 \\
\hline & Penurunan kualitas wilayah dan akses pariwisata (k5) & 0,11 \\
\hline & Degradasi budaya dan kearifan lokal (k6) & 0,09 \\
\hline \multirow{3}{*}{$\begin{array}{l}\text { Opportunities } \\
\text { (kesempatan) }\end{array}$} & $\begin{array}{l}\text { Pelatihan pengembangan keahlian untuk masyarakat dan staf } \\
\text { kepariwisataan dari pemerintah daerah dan swasta }(\mathrm{k} 7)\end{array}$ & 0,15 \\
\hline & Spesifikasi obyek wisata $(\mathrm{k} 8)$ & 0,07 \\
\hline & Peningkatan kunjungan wisatawan(k9) & 0,08 \\
\hline \multirow{4}{*}{ Treats (ancaman) } & Komplain wisatawan (k10) & 0,12 \\
\hline & Kompetisi dari daerah wisata lain yang sejenis (k11) & 0,07 \\
\hline & Rendahnya dukungan pemerintah (k12) & 0,05 \\
\hline & Jumlah Bobot & 1 \\
\hline
\end{tabular}


Analisis SWOT menentukan prioritas strategi pengembangan ekowisata Kampung Tajur sesuai dengan kondisi lokal.
Berdasarkan Tabel 2, setiap kriteria mempunyai bobot nilai yang menjadi faktor pengkali pada analisis matriks strategi.

\section{Pengembangan Ekowisata Berdasarkan Fuzzy Quantitative Strategic Planning Matrix (FQSPM)}

Angka Fuzzy dipakai untuk membantu penilaian kriteria pada QSPM. Penentuan nilai kriteria ditentukan dengan skala yang disesuai dengan skema

triangulasi angka Fuzzy (Gambar 1). Nilai ditentukan dengan menjumlahkan setiap angka Fuzzy pada masing-masing kriteria dan strategi.

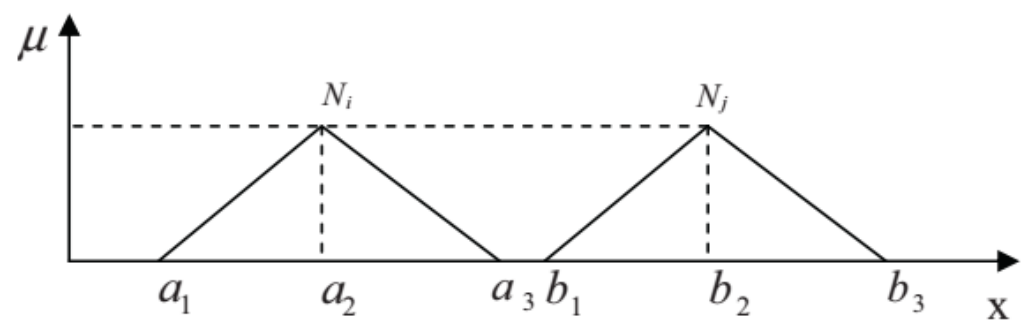

Gambar 1. Skema Triangulasi Angka Fuzzy (Hosseini dan Milani, 2012).

Berdasarkan Gambar 1, nilai kriteria ditentukan dengan rumus $\left(a_{1}+2 a_{2}+a_{3} / 2\right)$ untuk $N_{\mathrm{i}}$ dan $\left(b_{1}+2 b_{2}+b_{3} / 2\right)$ untuk $N_{\mathrm{j}}$ dan seterusnya. $N_{\mathrm{i}}$ adalah kriteria $N$ pada strategi $i$, sedangkan $N_{\mathrm{j}}$ adalah kriteria $N$ pada strategi $j$. Hosseini dan Milani (2012) telah mengembangkan penilaian untuk enam tingkatan fuzzy yang ditunjukkan pada Tabel 3.

Tabel 3. Definisi Enam Tingkat Penilaian Fuzzy.

\begin{tabular}{lcccccc}
\hline Kondisi & $\begin{array}{c}\text { Sangat } \\
\text { Rendah (SR) }\end{array}$ & Rendah (R) & Sedang (S) & Baik (B) & Baik Sekali (BS) & $\begin{array}{c}\text { Sangat Baik } \\
\text { Sekali (SB) }\end{array}$ \\
\hline $\begin{array}{l}\text { Skala } \\
\text { fuzzy }\end{array}$ & $(0 ; 0,05 ; 0,1)$ & $(0,1 ; 0,25 ; 0,3)$ & $(0,3 ; 0,45 ; 0,5)$ & $(0,5 ; 0,65 ; 0,7)$ & $(0,7 ; 0,85 ; 0,9)$ & $(0,9 ; 1 ; 1)$ \\
\hline
\end{tabular}

Sumber: (Hosseini dan Milani, 2012).

Tabel 3 menunjukkan nilai $a_{1}, a_{2}$, dan $a_{3}$. Sebagai contoh, pada kondisi S, maka $a_{1}=$ $0,3, a_{2}=0,45$, dan $a_{3}=0,5$. Nilai kriteria dihasilkan dari rerata $\left(a_{1}+2 a_{2}+a_{3} / 2\right)$.

Tabel 4. Evaluasi Strategi Pengembangan Ekowisata Berdasarkan FQSPM.

\begin{tabular}{l|cccccccccccc}
\hline Kriteria & $\mathrm{k} 1$ & $\mathrm{k} 2$ & $\mathrm{k} 3$ & $\mathrm{k} 4$ & $\mathrm{k} 5$ & $\mathrm{k} 6$ & $\mathrm{k} 7$ & $\mathrm{k} 8$ & $\mathrm{k} 9$ & $\mathrm{k} 10$ & $\mathrm{k} 11$ & $\mathrm{k} 12$ \\
\hline Bobot & 0,04 & 0,07 & 0,12 & 0,03 & 0,11 & 0,09 & 0,15 & 0,07 & 0,08 & 0,12 & 0,07 & 0,05 \\
\hline $\begin{array}{l}\text { Strategi } \\
1\end{array}$ & 0,609 & 0,767 & 0,829 & 0,461 & 0,207 & 0,431 & 0,089 & 0,387 & 0,09 & 0,100 & 0,117 & 0,299 \\
\hline $\begin{array}{l}\text { Strategi } \\
2\end{array}$ & 0,127 & 0,073 & 0,421 & 0,103 & 0,492 & 0,401 & 0,118 & 0,963 & 0,795 & 0,605 & 0,236 & 0,147 \\
\hline Strategi & 0,427 & 0,385 & 0,217 & 0,638 & 0,013 & 0,687 & 0,386 & 0,104 & 0,787 & 0,421 & 0,391 & 0,572 \\
\hline
\end{tabular}




\begin{tabular}{l|cccccccccccc}
\hline 3 & \multicolumn{10}{|c}{} \\
4
\end{tabular}

Berdasarkan Tabel 4, maka disusun prioritas strategi pengembangan ekowisata yang ditunjukkan dengan Tabel 5. Nilai prioritas

dihasilkan dari penjumlahan nilai kriteria kali bobot pada masing-masing strategi

Tabel 5. Prioritas Strategi Pengembangan Ekowisata Kampung Tajur.

\begin{tabular}{|c|c|c|}
\hline \multirow{2}{*}{$\begin{array}{l}\text { Strategi } \\
\text { Strategi } 2 \\
\text { (pengembangan potensi wisata alam yaitu bukit batu dan air } \\
\text { terjun) }\end{array}$} & $\begin{array}{l}\text { Nilai Prioritas } \\
\end{array}$ & Prioritas \\
\hline & u dan air & 1 \\
\hline $\begin{array}{l}\text { Strategi } 3 \\
\text { (pengembangan kesenian musik tradisional) }\end{array}$ & 0,387 & 2 \\
\hline $\begin{array}{l}\text { Strategi } 4 \\
\text { (pengembangan makanan tradisional) }\end{array}$ & 0,376 & 3 \\
\hline \multicolumn{3}{|l|}{$\begin{array}{l}\text { Strategi } 1 \\
\text { (pengembangan kegiatan masyarakat adat) }\end{array}$} \\
\hline \multicolumn{3}{|l|}{$\begin{array}{l}\text { Berdasarkan Tabel 5, prioritas } \\
\text { pertama untuk pengembangan pariwisata } \\
\text { Kampung Tajur adalah Stratei } 2 \text { yaitu } \\
\text { pengembangan potensi wisata alam. Strategi } \\
\text { ini sesuai dengan kondisi Kampung Tajur } \\
\text { yang berada di kaki Gunung Burangrang. } \\
\text { Kampung Tajur memiliki suhu dingin } \\
\text { dengan kondisi tanah yang subur dan berada } \\
\text { Kesimpulan }\end{array}$} \\
\hline $\begin{array}{l}\text { Kampung Tajur sebagai daerah } \\
\text { ekowisata memiliki beberapa potensi wisata } \\
\text { yang belum dikelola oleh masyarakat Tajur } \\
\text { dan pemerintah daerah. Potensi } \\
\text { pengembangan yang telah diidentifikasi } \\
\text { yaitu kegiatan masyarakat adat, potensi } \\
\text { wisata alam, kesenian musik tradisional, dan }\end{array}$ & $\begin{array}{l}\text { analisis FQSPM, maka c } \\
\text { pengembangan potensi el } \\
\text { Pengembangan potensi } \mathrm{w} \\
\text { batu dan air terjun); } 2 \\
\text { musik tradisional; } 3 \text { ) } \\
\text { makanan tradisional; } 4 \\
\text { kegiatan masyarakat adat. }\end{array}$ & $\begin{array}{l}\text { roleh prioritas } \\
\text { isata yaitu: 1) } \\
\text { a alam (bukit } \\
\text { Pengembangan } \\
\text { Pengembangan } \\
\text { Pengembangan }\end{array}$ \\
\hline
\end{tabular}

\section{Ucapan Terima Kasih}

Ucapan terima kasih saya sampaikan kepada ketua RT 10 Kampung Tajur, Aa Asep dan Gigin dari perwakilan pemuda Kampung

Tajur atas keramahannya telah membantu kami dan memberikan informasi aktual tentang kondisi dan potensi Kampung Tajur

\section{Referensi}

Bulatović, J., dan Rajović, G. (2016): Applying Sustainable Tourism

Indicators to Community-Based Ecotourism Tourist village Eco- 
katun Štavna, European Journal of Economic Studies, 16(2), 309-331, https://doi.org/10.13187/es.2016.16 .309.

Büscher, B., dan Davidov, V. (2016): Environmentally induced displacements in the ecotourism extraction nexus, Area, 48(2), 161167 , https://doi.org/10.1111/area.12153.

Candrea, A. N., dan Anu, A. H. E. R. T. (2015): Developing ecotourism destinations in Romania. A case study approach, Bulletin of the Transilvania University of Braşov, 8(2), 163-174.

Hosseini, H., dan Milani, A. S. (2012): An improvement of quantitative strategic planning matrix using multiple criteria decision making and fuzzy numbers, Applied Soft
Computing Journal, 12(8), 22462253, https://doi.org/10.1016/j.asoc.2012. 03.010 .

Paresashvili, N. (2014): Major Tasks of Ecotourism Management in Georgia, Procedia - Social and Behavioral Sciences, 156(April), 170-173, https://doi.org/10.1016/ j.sbspro.2014.11.164.

Sikkim, W., Ashok, S., Tewari, H. R., Behera, M. D., dan Majumdar, A. (2017): Development of ecotourism sustainability assessment framework employing Delphi, C \& I and participatory methods: A case study of KBR, Tourism Management Perspectives, 21, 2441, https://doi.org/10.1016/j.tmp.2016. 10.005 . 